\title{
Regeneration capacity and threats to mangrove areas on the southern coast of Oriental Mindoro, Philippines: Implications to mangrove ecosystem rehabilitation
}

\author{
AARON FROILAN M. RAGANAS ${ }^{1, \bullet}$, ANNALEE S. HADSALL ${ }^{2}$, NELSON M. PAMPOLINA ${ }^{3}$, \\ STEFAN HOTES ${ }^{4}$, DAMASA B. MAGCALE-MACANDOG ${ }^{2}$ \\ ${ }^{1}$ Department of Biological Sciences and Environmental Studies, College of Science and Mathematics, University of the Philippines Mindanao. Mintal, \\ Davao City 8022, Philippines. Tel.: +63-82-293-0302, Fax.: +63-82-293-0312, • email: amraganas@ up.edu.ph \\ ${ }^{2}$ Institute of Biological Sciences, College of Arts and Sciences, University of the Philippines Los Baños. College, Laguna 4031, Philippines \\ ${ }^{3}$ Department of Forest Biological Sciences, College of Forestry and Natural Resources, University of the Philippines Los Baños. College, Laguna 4031, \\ Philippines \\ ${ }^{4}$ Chuo University. 1-13-27 Kasuga, Bunkyo-ku, Tokyo 112-8551, Japan
}

Manuscript received: 16 May 2020. Revision accepted: 18 July 2020.

\begin{abstract}
Raganas AFM, Hadsall AS, Pampolina NM, Hotes S, Magcale-Macandog DB. 2020. Regeneration capacity and threats to mangrove areas on the southern coast of Oriental Mindoro, Philippines: Implications to mangrove ecosystem rehabilitation. Biodiversitas 21: 3625-3636. Regeneration capacity is important as it determines the fate of an ecosystem. This study assessed six mangrove areas in the southern coast of Oriental Mindoro, Philippines to evaluate their regeneration capacity status. Four mangrove ecotypes were delineated namely seaward, middle, landward and riverine zones at each mangrove ecosystem, where dominant mangrove species were identified and selected for regeneration capacity study. Three subplots measuring $1 \mathrm{x} 1 \mathrm{~m}^{2}$ were laid within the five $10 \mathrm{x} 10$ $\mathrm{m}^{2}$ survey plots established per zone. The juveniles were counted and categorized according to their height classes, using linear regeneration sampling method; where: $R C I(\leq 40 \mathrm{~cm})$ considered seedlings; RCII $(41-150 \mathrm{~cm})$ as saplings; and RCIII $(151-\leq 300 \mathrm{~cm})$ as small trees. Potential threats both anthropogenic and natural were determined through key informant interviews. Seven dominant species were identified across ecotypes in all mangrove sites, namely Avicennia marina, Avicennia rumphiana, Ceriops decandra, Rhizophora apiculata, Rhizophora mucronata, Sonneratia alba, and Xylocarpus granatum. RCI (seedlings) is the most abundant across mangrove sites irrespective of the dominant species. Fishpond operation within the mangrove stand is considered a major threat to the juveniles and most mangrove ecosystems. Therefore, protection and constant monitoring of these mangrove ecosystems are necessary to ensure regeneration success in the future.
\end{abstract}

Keywords: Dominant species, ecotypes, linear regeneration sampling, regeneration capacity, rehabilitation

\section{INTRODUCTION}

Mangrove ecosystem is one of the most productive ecosystems in the coastal areas of tropical and subtropical regions. Mangroves provide various ecosystem services especially protecting the coastal environment and serve as a breeding ground for marine aquatic species. The unique ecological functions of the ecosystem have already been known for decades. However, its resiliency has been affected by unrestrained human demands and climatic events (Ghosh et al. 2015; Duncan et al. 2016). The loss of mangrove cover around the world was primarily accounted for anthropogenic activities, particularly coastal developments (Curnick et al. 2019; Chowdhury et al. 2019). The enormous anthropogenic activities especially conversion of the ecosystem to urban settlements, aquaculture, tourism, mining, and infrastructure are among those that prompted the rapid degradation of the mangrove ecosystem (Kathiresan 2018; Chowdhury et al. 2019; Begam et al. 2020). Natural events such as sea-level rise, increased level of toxic elements in sediments, constant erosion due to strong tidal action, and storms have also impacted the mangrove ecosystem recovery (Chowdhury et al. 2019; Begam et al. 2020).

The decline of mangrove forests in the Philippines is attributed to salt pond development, excessive exploitation by the coastal dwellers, conversion to agriculture, industry, and settlements (Garcia et al. 2013). With this scenario, the national government has passed several environmental laws for the protection and proper utilization of the country's remaining mangrove stands. This has led to numerous planting initiatives by various civic groups and institutions, but unfortunately, most of these programs were not successful. The mishaps are directly associated with the planting of inappropriate mangrove species in unsuitable substrates (Primavera et al. 2011). Failures came off due to ambiguous implementing rules and regulations and the lack of science-guided protocols (Primavera et al. 2011; Garcia et al. 2013). In 2014, Cayabyab conducted the mangrove assessment in Oriental Mindoro and interestingly found out a promising increase of mangrove cover in the province. Though expansion has been generally observed, still there is a decline of mangrove stands in specific mangrove areas in the province driven by anthropogenic activities. The cutting of mangrove trees is still prevalent due to fishpond 
expansion, house construction, and charcoal making. The increasing number of coastal residents in some municipalities is taking place, thereby converting some mangrove forests into residential areas.

Many studies in other countries have reported that the consequence of mangrove ecosystem degradation is apparent in the poor growth performances of plants, as well as the decline in density and coverage of the mangrove forest (Chowdhury et al. 2019; Begam et al. 2020). Accordingly, with high levels of degradation, secondary succession will be delayed, and gradually the ecosystem will become susceptible to the brink of extinction as their homeostatic functioning collapses (Begam et al. 2020). Regeneration can also be delayed by the lack of propagules, competition, pollution, and poor soil conditions in a particular mangrove area (Machenga and Ali 2014). It is in this event where human intervention is deemed necessary to fast track the recovery of the ecosystem through artificial re-establishment using planted seedlings (Alura and Alura 2016).

Regeneration capacity is an important aspect to study because it can be used to determine the capacity of the ecosystem to recover itself despite environmental pressures (Begam et al. 2020). The re-establishment of a once damaged ecosystem is driven by the establishment of the seedlings even it can take time to manifest (Lewis et al. 2005; Alura and Alura 2016; Begam et al. 2020). Regeneration potential of a mangrove stand in terms of seedling recruitment and survivorship is essential to be evaluated as it primarily drives population growth and determines the productivity of the mangrove ecosystem (Kathiresan et al. 2016). The resilience of mangrove forest ecosystems is dependent on regenerative potential of the mangrove plants (Krauss et al. 2008; Kathiresan et al. 2016). Thus, knowledge of regeneration capacity is crucial for both the protection and restoration of the mangrove ecosystem.

This present study was conducted to (i) assess the dominant mangrove species and their juveniles in four mangrove ecotypes-seaward, middle, landward and riverine zones in six mangrove ecosystems in the southern coast of Oriental Mindoro; (ii) determine their regeneration capacity status; and (iii) identify the potential threats both anthropogenic and natural that could potentially impact the regeneration of each mangrove ecosystem. The results of this study will provide information on the regeneration status of the mangrove ecosystems in the southern coast of Oriental Mindoro albeit their long exposure to disturbances. Identification of regeneration patterns and threats is important in the design and monitoring of the sustainable management of the mangrove ecosystem.

\section{MATERIALS AND METHODS}

\section{Study sites}

The study sites are located in the southern district (from $12^{\circ} 53^{\prime} \mathrm{N}$ and $121^{\circ} 29^{\prime} \mathrm{E}$ to $12^{\circ} 19^{\prime} \mathrm{N}$ and $121^{\circ} 21^{\prime} \mathrm{E}$ ) of Oriental Mindoro province consisting of six municipalities namely Gloria, Bansud, Bongabong, Roxas, Mansalay and
Bulalacao (Figure 1). As of 2010, these municipalities cover approximately 661.02 hectares of mangrove forests (Cayabyab 2014). The mangrove site in each municipality was identified through a consultation meeting with the respective local environment authorities prior to the conduct of the study. The selection process was based on the distinguished zonation patterns observed in the mangrove ecosystem including seaward, middle, landward, and riverine zones. The seaward was designated as zone at the intertidal where mangroves are directly submerged to seawater; while middle zone as the transition zone between the seaward and landward, where a combination of species from both zones was observed. The distance from the intertidal zone depends on the geologic formation of the mangrove stand. Landward was designated as the zone inland from the boundary of the middle zone, while riverine as the zone along the river banks.

\section{Sampling procedures}

A stratified random sampling method was employed to determine the dominant mangrove species and their juveniles in a mangrove community. At each sampling site, the ecotypes namely seaward, middle, landward and riverine zones were delineated. Five plots were established at each zone, either in parallel or perpendicular orientation depending on the size and accessibility of the mangrove area. The plots were laid within a 100-meter transect line at 20-meter intervals. Each plot measuring $10 \times 10 \mathrm{~m}^{2}$ was established to determine the dominant mangrove species. The dominant species were identified based on their density and basal area cover. Species identification was done on-site using the field guide to Philippine mangroves by Primavera (2004) and based on the knowledge of the local field guides.

\section{Regeneration capacity}

The information on regeneration capacity of dominant mangrove species was obtained using linear regeneration sampling method. Three subplots measuring $1 \times 1 \mathrm{~m}^{2}$ were established in an alternating diagonal position within each $10 \times 10 \mathrm{~m}^{2}$ quadrat laid per ecotype. The size of the subplot was a modification from the various methods employed for the assessment of mangrove seedlings but replicated three times to ensure statistically sound data. All the juveniles of dominant mangrove species with diameter at breast height $(\mathrm{DBH})$ of $\leq 5 \mathrm{~cm}$ were measured and considered in the regeneration study. The height of the juveniles was then measured and classified based on regeneration class (RCs) categories. Regeneration Class I (RCI) with heights $\leq 40 \mathrm{~cm}$ were considered seedlings; RCII with heights between 41 $\mathrm{cm}$ to $150 \mathrm{~cm}$ as saplings; and RCIII with heights 151 $\mathrm{cm}$ but $\leq 300 \mathrm{~cm}$ were considered small trees. The employment of this regeneration class category was the basis to estimate life stages of the juveniles of dominant mangrove species. The data from different RC categories were then used to determine the regeneration condition of the particular mangrove ecosystem. A total of 60 subplots were established for the assessment of the regenerating plants per sampling site. However, the number of subplots was reduced in some areas, due to the absence of mangroves along the seaward zone. 

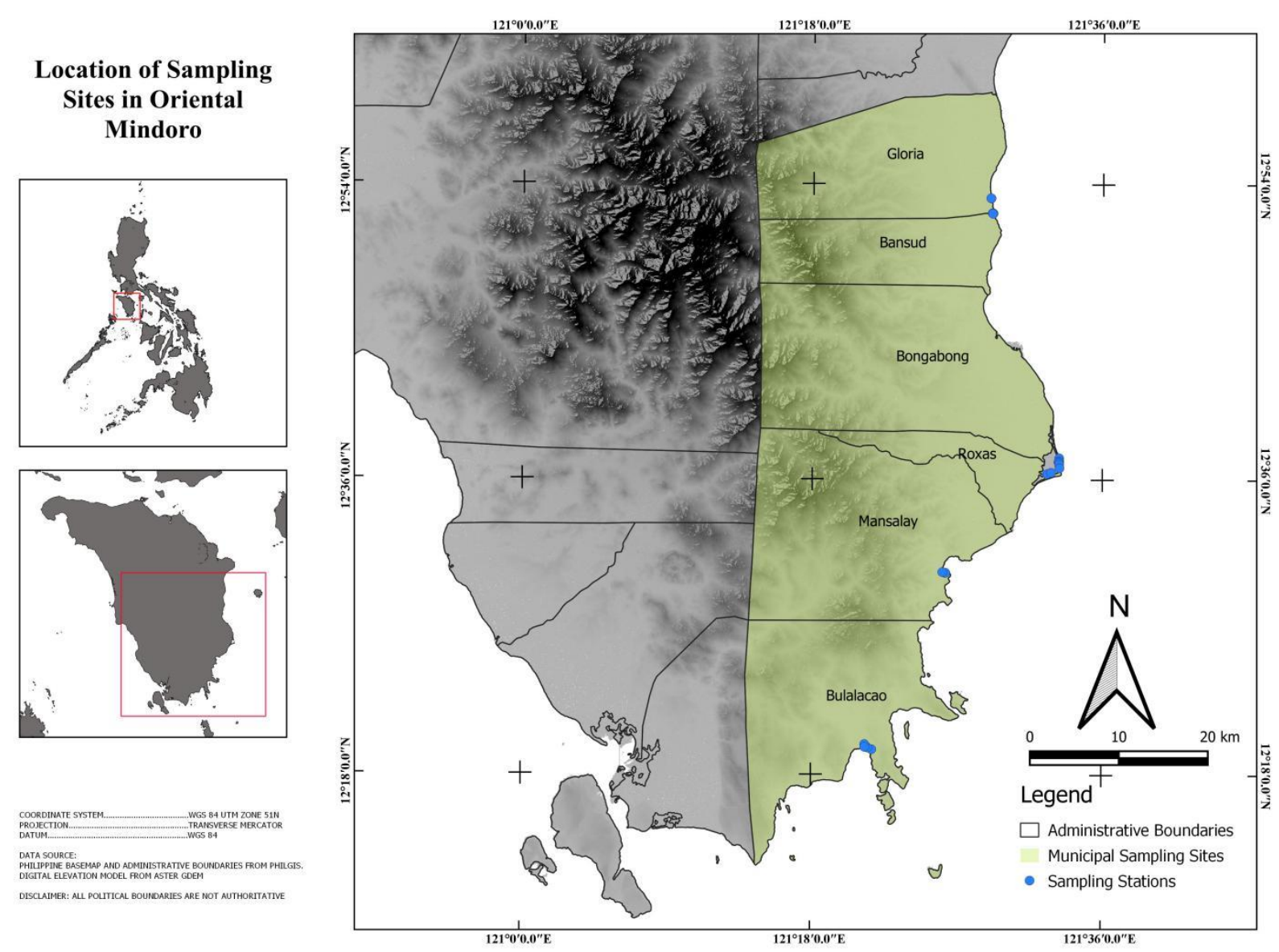

Figure 1. Location of six study sites in the southern coast of Oriental Mindoro, Philippines

\section{Data analyses}

The similarities of dominant mangrove species across zones in all mangrove areas were determined using Jaccard similarity index and presented through cluster dendrogram. The regeneration (RCs) of the dominant mangrove species per zone at each mangrove ecosystem were compared using a non-parametric Kruskal-Wallis test after the data was subjected to a normality test and found out to be nonGaussian. This univariate analysis was performed to detect significant differences in the RC densities among dominant species. The significant difference detected was further analyzed using Mann-Whitney's test to identify significantly different RC (s). The comparison between the densities of juveniles of co-dominant species per zone was determined using Wilcoxon signed-rank test to detect significant differences. This non-parametric test was also used to compare the RCs of only one dominant species identified in a particular zone. The computed values were then compared to the p-value at a marginal level of significance of $<0.05$. All these statistical analyses were performed using the PAST software version 4.02.

\section{Threats to mangrove ecosystems}

Specific threats to each mangrove ecosystem were determined through a face to face interview using the survey questionnaire we designed. The key informants directly involved in the conservation and management of mangroves in each municipality were selected as the participants. The key informants include representatives from the Municipal Environment and Natural Resources Office (MENRO), Municipal Agriculture Office (MAO), Coastal Resources Management Office (CRMO), and 'Bantay-dagat' (Coast guards) of each respective municipality. These key informants were selected as they have better knowledge regarding the scenarios on their respective mangrove areas. The study also included few coastal households living near the mangrove area to gather additional information and be more holistic in our approach. Only one member per household was interviewed, those with minimum residency of at least 10 years in the area. The interview process was also a face to face basis, where questions were personally asked the participants. The survey questionnaire was composed of sets of questions regarding the observed past and present threats to the mangrove ecosystem. The interview was carried out to obtain necessary information on human activities and natural calamities that had occurred in the mangrove area such as urbanization, clearing/cutting, aquaculture, and agriculture activities, water pollution, flood, siltation, coastal erosion, sea-level rise, strong tidal waves, typhoon/storm surges, increase in temperature and changes in precipitation patterns that could possibly impact 
mangrove ecosystem. The frequency of the observed threats was also noted based on the number of respondents who agreed if they frequently observed a particular threat or not. The results presented were the numbers and percentages of the respondents in each municipality who agreed to observe types of threats in their respective mangrove areas. Information on the length of years when these threats observed was also collected. A total of 113 respondents have participated in the survey in all study sites.

Table 1. Description of the study sites in the southern coast of Oriental Mindoro, Philippines

\begin{tabular}{lll}
\hline Location & Coordinates & Description \\
\hline Agsalin, Gloria & $12^{\circ} 53^{\prime} 19.52^{\prime \prime} \mathrm{N}$, & The study area is located in barangay Agsalin, one of the coastal barangays in the \\
$121^{\circ} 29^{\prime} 57.48^{\prime \prime} \mathrm{E}$ & $\begin{array}{l}\text { municipality. The seaward zone of the mangrove area is dominated by the aroma tree } \\
(0-5 \text { masl })\end{array}$ & $\begin{array}{l}\text { (Fabaceae) forming a monospecific band along the shoreline. The mangrove vegetation } \\
\text { structure was considered an early growth stand as evidenced by the regenerating mangrove } \\
\text { trees with small stem sizes. The mangrove area has been rehabilitated with Rhizophora } \\
\text { mucronata species near the seafront. The area is inundated by the brackish water through a } \\
\text { huge river basin during high tide. There are few residents living near the mangrove area, } \\
\text { together with agriculture farming at the back of the mangrove stand. }\end{array}$
\end{tabular}

Tambong, Bansud $12^{\circ} 52^{\prime} 14.89^{\prime \prime} \mathrm{N}$, $121^{\circ} 29^{\prime} 06.24^{\prime \prime} \mathrm{E}$ (4-6 masl)

Dayhagan, Bongabong

Dalahican, Roxas

Cabalwa, Mansalay

$12^{\circ} 30^{\prime} 18.87 " \mathrm{~N}$, $121^{\circ} 26^{\prime} 17.59^{\prime \prime} \mathrm{E}$ (0-8 masl)

Caratao, Bulalacao

$12^{\circ} 19^{\prime} 38.62 " \mathrm{~N}$, $121^{\circ} 21^{\prime} 30.46^{\prime \prime} \mathrm{E}$ (0-10 masl)

$12^{\circ} 37^{\prime} 06.04^{\prime \prime} \mathrm{N}$, $121^{\circ} 33^{\prime} 16.47^{\prime \prime} \mathrm{E}$ (3-7masl)

$12^{\circ} 36^{\prime} 43.31^{\prime \prime} \mathrm{N}$, $121^{\circ} 33^{\prime} 20.16^{\prime \prime} \mathrm{E}$ (2-9 masl)
Bansud is a second class municipality located next to the municipality of Gloria. The study area is located in barangay Tambong with shoreline also dominated by the aroma tree. The mangrove area is situated adjacent to the riverbank. Beach resorts and rice agriculture are found present near the mangrove area. The mangrove area is a natural stand, structurally old growth with large tall mangrove trees.

Bongabong has the largest fishpond area in the whole province grown with milkfish, prawn, crabs, and tilapia. The study site is located in Dayhagan, with mangrove structure characterized as early growth due to the abundance of regenerating mangrove trees with small stem sizes. The mangrove stand is a mix of natural and rehabilitated species. A large portion of the mangrove stand was converted into fishpond area but has been abandoned and rehabilitated with $R$. mucronata species. No mangrove trees were found thriving along the shore, only aroma tree, coconut, and other palm species.

Roxas is the smallest municipality in the province. The study area is located in barangay Dalahican, with mangrove stand characterized as early growth due to the abundance of regenerating and small diameter-sized mangrove trees as well. Large portion of the stand was converted into fishpond area but few ponds were abandoned and were rehabilitated with $R$. mucronata species. An array of beach resorts together with a huge coastal community is located adjacent to the mangrove stand.

Mansalay has an estimated mangrove cover of 20.34 hectares. This has decreased in size from 52.2 hectares in the $1990 \mathrm{~s}$, and considered as the smallest in the whole southern municipalities. The decline in size was primarily attributed to fishpond establishments within the mangrove area (Cayabyab 2014). The study site is located in Cabalwa, with a small community residing near the mangrove area. The intertidal zone with seagrass bed was planted with $R$. mucronata species. The mangrove vegetation structure was characterized as natural old-growth stand with large and tall mangrove trees growing in all zones. Species Avicennia marina was found dominant occupying the entire mangrove stand.

Bulalacao is the southernmost municipality in the province. The mangrove site is located in Caratao lake which serves as a passageway for seawater to enter inlands through river networks within the mangrove stand. The vegetation structure was considered early growth with abundant small stem-sizes mangrove trees. There were fishpond operations within the mangrove stand but most of it was already abandoned. The seafront area was planted with $R$. mucronata species as a product of the rehabilitation activities of the local government. A huge community also resides adjacent to the mangrove stand. 


\section{RESULTS AND DISCUSSION}

\section{Dominant mangrove species across ecotypes in all mangrove sites}

Three of the seaward zones specifically in the mangrove areas of Gloria, Bansud and Bongabong were not considered due to the absence of mangroves along the shore. A total of seven dominant mangrove species were identified across ecotypes in all study sites namely Avicennia marina, Avicennia rumphiana, Ceriops decandra, Rhizophora apiculata, Rhizophora mucronata, Sonneratia alba and Xylocarpus granatum (Figure 2). Similarities of dominant species revealed three major clusters showing $R$. apiculata and A. rumphiana as common dominant species in the ecotypes included in Group I (GI) cluster, while species A. marina in Group II (GII) and R. mucronata in Group III (GIII) clusters, respectively. The zonal dominance of mangrove species across ecotypes in all mangrove sites revealed that $A$. marina, $R$. apiculata, $R$. mucronata, and A. rumphiana have the capacity to dominate in all zones. Meanwhile, species $C$. decandra can dominate from middle to landward zone, and $X$. garantum in landward only. Species S. alba was only found dominant in the riverine zone specifically in Bansud. Moreover, the group III cluster has very low similarities with groups I and II attributed to the species $X$. granatum found dominant in the landward zone of the mangrove stand in Gloria.

\section{Regeneration capacity}

The abundance of juveniles of various dominant mangrove species per ecotype was compared to determine which among them will highly contribute to the regeneration capacity of each mangrove ecosystem. In Gloria (Figure 3.A), highest regeneration was observed in the riverine zone while lowest in the middle zone. The highest regeneration in riverine was accounted for high RCI of $R$. apiculata, though no significant differences were detected among the RCs $(\mathrm{p}=0.65472)$. In the middle zone, $R$. mucronata had abundant juveniles compared with $C$. decandra. RCI was considered the most abundant among the RCs of both species. Further, R. mucronata had also abundant RCIII while $C$. decandra had no RCIII recorded. Statistical tests revealed no significant differences detected between and among the RCs of both species as indicated by their p-values greater than 0.05. In the landward zone, juveniles of $X$. granatum were found abundant than the juveniles of $R$. mucronata. Though the RCI of $R$. mucronata was less abundant than the RCI of X. granatum, the former species had more RCII and RCIII than the latter species. Also, no significant differences were detected in the RCs between and within species $(\mathrm{p}=\geq 0.05)$. Overall, the mangrove vegetation in Gloria had abundant RCI for all dominant species.

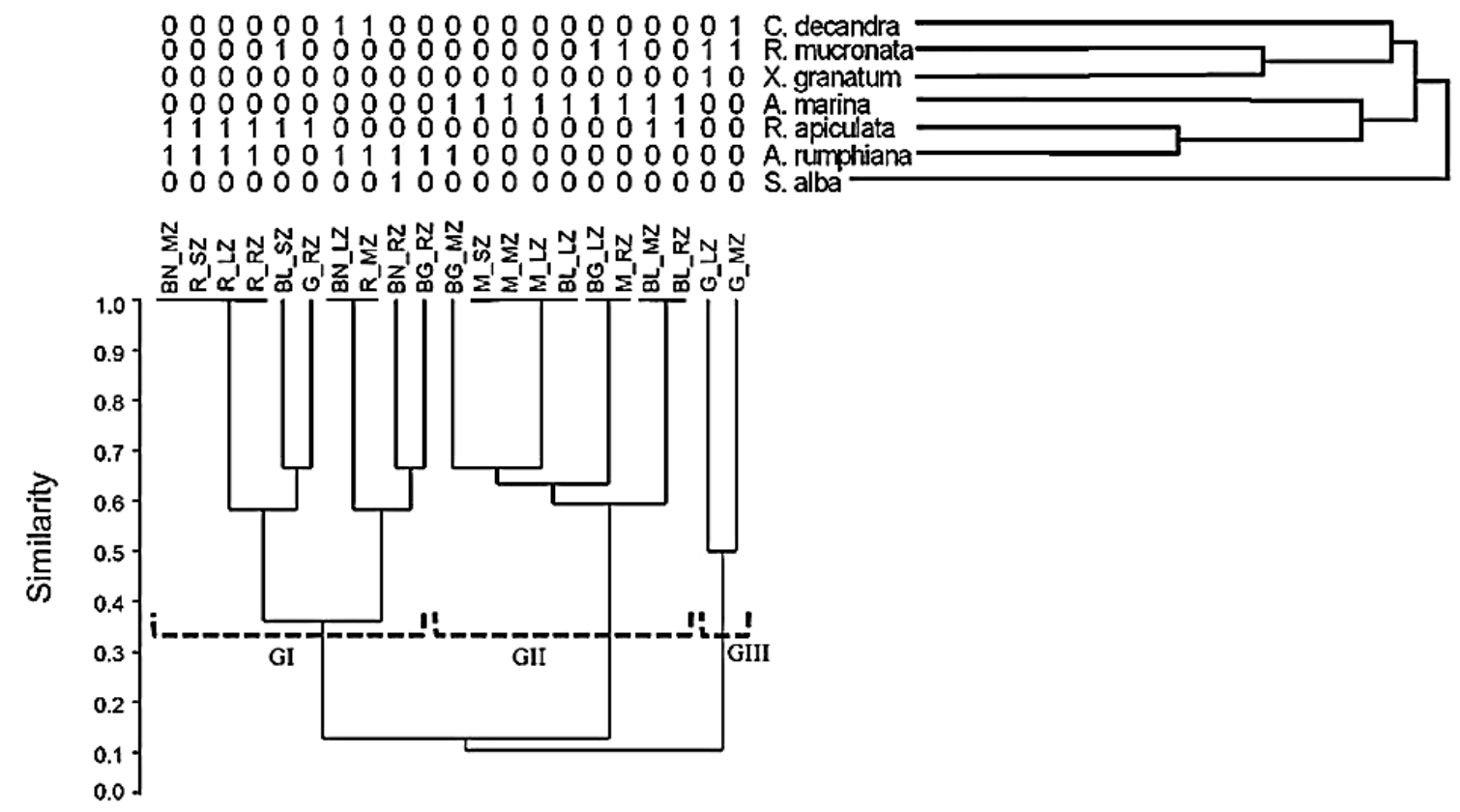

Figure 2. Cluster dendrogram showing similarities of dominant mangrove species across zones of the mangrove stands in all study sites using Jaccard similarity index. Codes for each site and zone: Gloria (G); Bansud (BN); Bongabong (BG); Roxas (R); Mansalay (M); Bulalacao (BL). Ecotypes: Seaward Zone (SZ); Middle Zone (MZ); Landward Zone (LZ); Riverine Zone (RZ). Species code: A. marina (Avicennia marina); A. rumphiana (Avicennia rumphiana); C. decandra (Ceriops decandra); R. apiculata (Rhizophora apiculata); $R$. mucronata (Rhizophora mucronata); S. alba (Sonneratia alba); X. granatum (Xylocarpus granatum) 
In Bansud (Figure 3.B), the regeneration is almost similar in all ecotypes. Statistical analysis revealed no significant differences in the abundances of RCs between and within species in all ecotypes $(\mathrm{p}=\geq 0.05)$. However, $A$. rumphiana had more abundant juveniles than $R$ apiculata in the middle zone of the mangrove stand. In the landward zone, most abundant juveniles were accounted for $C$. decandra. Meanwhile, A. rumphiana had more abundant juveniles than $S$. alba in the riverine zone. The density of juveniles of all the dominant species in each ecotype was mainly contributed by their RCI except for $S$. alba in the riverine zone, which had an abundant RCII (no RCIII recorded). Nevertheless, the juveniles belonging to RCI stage were also abundant in the mangrove stand of Bansud.

In Bongabong (Figure 3.C), regeneration was highest in middle zone, followed by landward and riverine zones, respectively. The juveniles of species $A$. rumphiana and $A$. marina in the middle zone were almost equally abundant, and no significant differences were detected between $(\mathrm{p}=0.65472)$ and within species $(\mathrm{p}=0.09509)$. However, most abundant juveniles were accounted for A. Marina even though no RCIII was recorded for the species. In the landward zone, most abundant juveniles were accounted for A. marina. Meanwhile, its co-dominant species $R$. mucronata, had no RCs II and III recorded because the species is still on its flowering stage, hence, only few juveniles were recorded. Between species, statistical analysis revealed significant differences between densities of juveniles of both species ( $\mathrm{p}=0.01088$ ), where species $A$. marina had significantly abundant juveniles accounted for its RCI ( $\mathrm{p}=0.03199)$. In the riverine zone, the RCI of species A. rumphiana was found abundant but no significant difference was detected between its RCs I and II $(p=0.17971)$, hence no RCIII was recorded for the species. On the other hand, only few juveniles belonging to RCIII were recorded in the whole mangrove stand. This was attributed to the first reproductive cycle of most dominant species, since the mangrove stand is still recovering from being heavily disturbed due to fishpond activities in the past.

In the mangrove stand of Roxas (Figure 4.D), the most abundant juveniles in the seaward zone were accounted for species A. rumphiana. Only RCs I and II were recorded for its co-dominant species $R$. apiculata, with RCII being the most abundant. No significant differences were detected between $(p=0.7495)$ and within $(p=0.3679)$ species in the zone. A similar pattern was observed in the middle and landward zones, with $A$. rumphiana having the most abundant juveniles highly contributed by its RCI in both zones. Meanwhile, the juveniles of the co-dominant species C. decandra in the middle zone, had more abundant RCII than its RCI (no RCIII recorded). By comparing the densities of RCs between species, no significant difference was detected $(\mathrm{p}=0.7517)$. However, the RCII of $C$. decandra was more abundant than the RCII of $A$. rumphiana. In the landward zone, no significant differences were also detected between $(\mathrm{p}=0.50125)$ and within $(\mathrm{p}=0.1516)$ juveniles of $A$. rumphiana and $A$. marina species. However, the RCI of both species was found abundant among their RCs. In the riverine zone, most abundant juveniles were accounted for species $R$. apiculata, highly contributed by its RCII. For $A$. rumphiana species, its RCI was the most abundant. By comparing the RCs between species, no significant difference was detected $(\mathrm{p}=0.65472)$ but the RCI of $A$. rumphiana was more abundant than the RCI of $R$. apiculata. However, the RCII of the latter species was more abundant than the RCII of the former species. No RCIII was recorded for both species and no significant differences were detected $(\mathrm{p}=0.1478)$ among their $\mathrm{RCs}$ in the zone. Generally, juveniles belonging to RCI stage were also found abundant in the mangrove site in Roxas. It was only in the riverine zone where most juveniles were already on their RCII stage.

In Mansalay (Figure 4.E), almost all zones had similar regeneration densities except for riverine with very low regrowths. Species A. marina was found dominant in all zones, but co-dominated by $R$. mucronata in the riverine zone. Statistical analysis revealed significant differences among the RCs of $A$. marina in the seaward ( $\mathrm{p}=0.05472$ ), middle $(\mathrm{p}=0.05471)$, and landward $(\mathrm{p}=0.05471)$ zones, respectively. The species had significantly higher RCI compared with other RCs in these zones. In the riverine zone, most abundant juveniles were accounted for species $R$. mucronata, contributed by both its RCs I and II. However, no significant differences were detected in the density and abundances of juveniles between $(p=0.8273)$ and within $(\mathrm{p}=0.1017)$ species in this zone. Most abundant juveniles in the entire mangrove stand were accounted for A. marina, significantly contributed by its RCI.

In Bulalacao (Figure 4.F), highest regeneration was observed in riverine, followed by landward, seaward, and middle zones, respectively. The species $A$. marina and $R$. apiculata were found dominant in the seaward, middle, and riverine zones of the stand. Most abundant juveniles in the seaward and middle zones were accounted for $R$. apiculata, while in riverine zone was A. marina. No RCIII was recorded for both species in these three zones. Statistical analysis revealed no significant differences detected between the RCs of both species in the seaward $(\mathrm{p}=0.65472)$ middle $(\mathrm{p}=0.65472)$ and riverine $(\mathrm{p}=0.17971)$ zones. However, the RCII of A. marina was more abundant than $R$. apiculata in the middle zone. In the landward zone, most abundant juveniles were accounted for A. marina. A significant difference was detected within the RCs of said species $(\mathrm{p}=0.01017)$. Mann-Whitney's test revealed that all the RCs of $A$. marina and $S$. alba were statistically significant from each other. But most abundant juveniles were accounted for by RCI of both species. Generally, the mangrove stand in Bulalacao had very low RCIII with only few individuals observed in the landward zone accounted for A. marina species. The juveniles under RCI stage were also abundant in the entire mangrove stand.

\section{Threats to mangrove ecosystems}

The threats observed in each mangrove ecosystem are presented in Table 2. Respondents from Gloria had 
observed all the threats in their mangrove stand. However, respondents in Bansud did not observe siltation, and no agriculture and aquaculture activities present in their mangrove stand. Storm surge and tidal actions during typhoons were not yet observed at the moment. On the other hand, respondents from Bongabong agreed that they observed all the threats except the influx of coastal residents near the mangrove area. According to them, the residents living near the mangrove stand are still those families that have been living there for a long time. In Roxas, respondents agreed that they observed all the threats to their mangrove ecosystem. In Mansalay, excessive flooding due to heavy rainfall was not yet observed, and the influx of coastal residents did not take place. Accordingly, there was a decline in the number of residents in the area due to lack of access to basic necessities. In
Bulalacao, strong tidal waves/surges, sea-level rise, coastal erosion, and agriculture were the threats not observed by the respondents.

Regarding the frequency of threats observed in all study sites, respondents from Bansud, Roxas, and Bulalacao avowed frequent increase of coastal residents in their area. Aquaculture activities within the mangrove stand were prevalent in most municipalities except for Gloria and Bansud. Meanwhile, rice agriculture farming was prevalent near the mangrove areas of Gloria and Mansalay. Water pollution due to household wastes was prevalent along the coasts of Roxas (Figure 5.A). The pollution was linked to the huge community residing near the coastal zone of the municipality. Selective cutting of mangrove trees is still prevalent in the municipalities of Bansud (Figure 5.B), Mansalay (Figure 5.C), and Bulalacao (Figure 5.D).
A. - R. mucronata

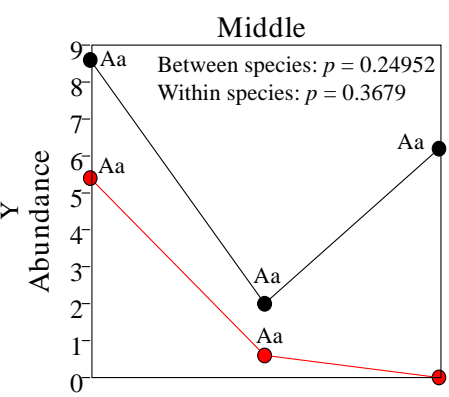

B. 二 A. rumphiana
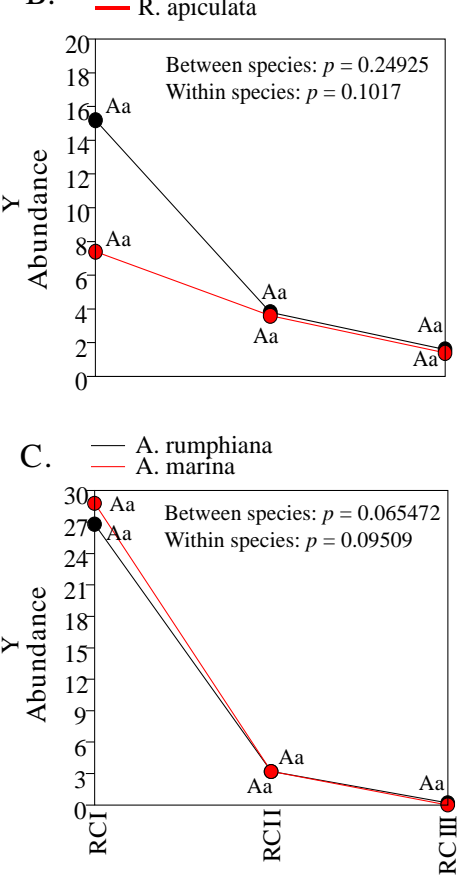

Regeneration Classes
R. mucronata
X. granatum
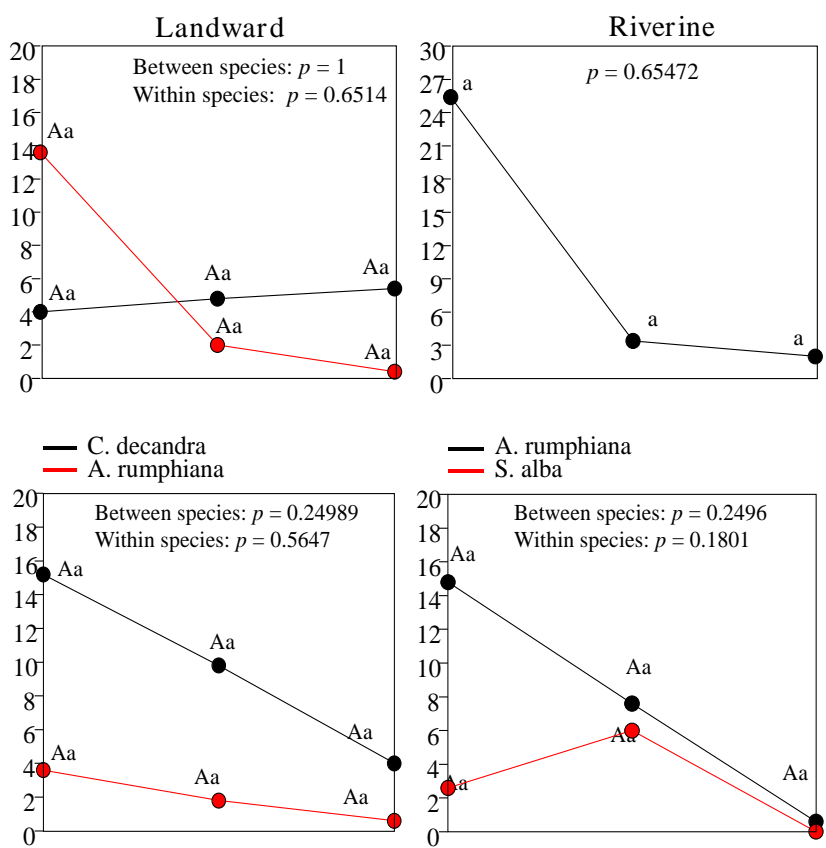

R. apiculata
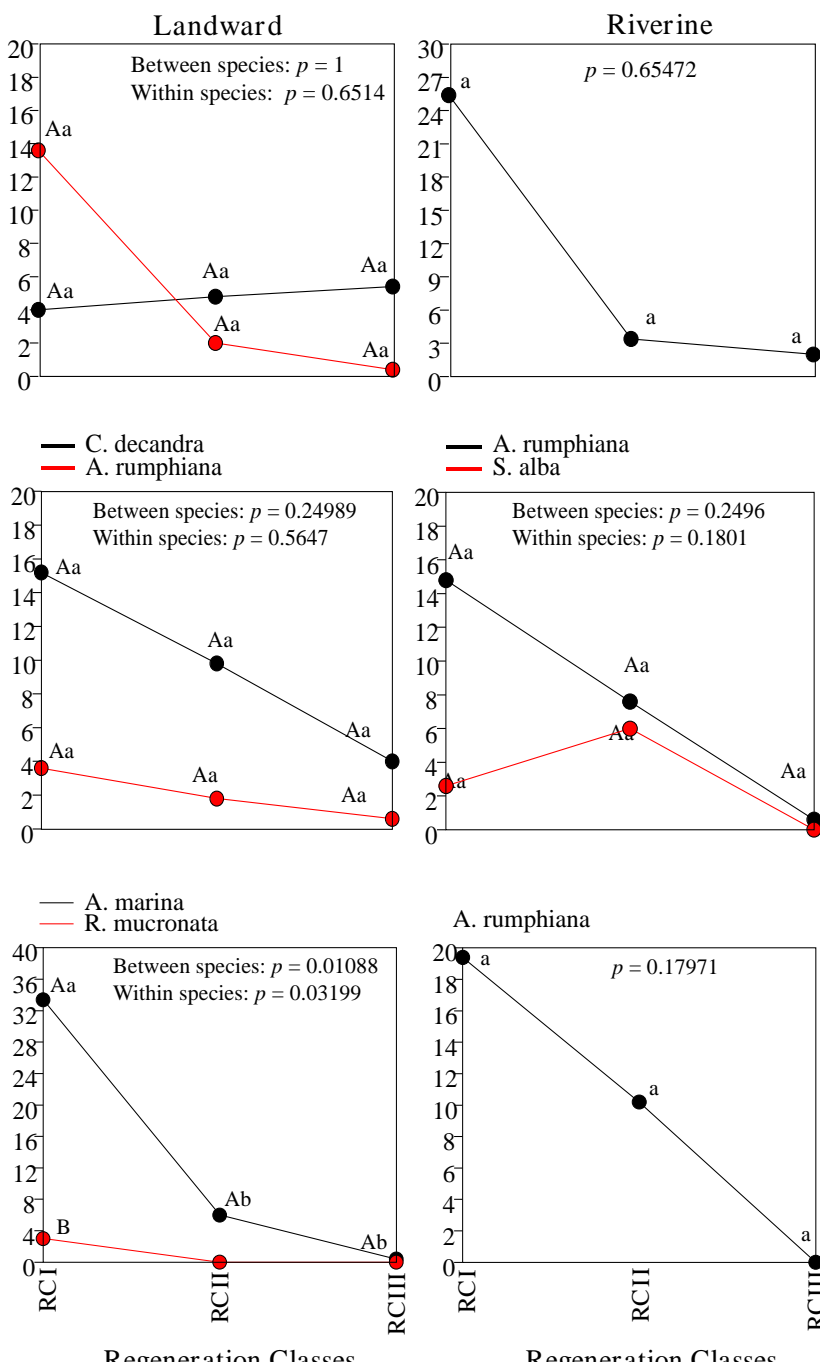

Regeneration Classes

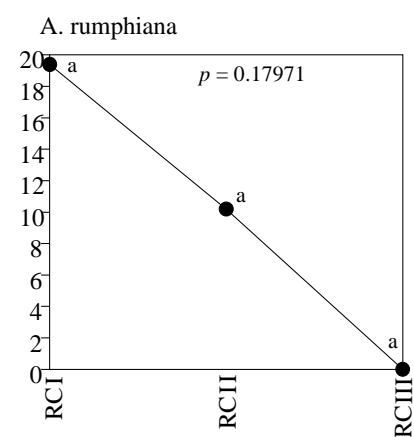

Regeneration Classes

Figure 3. Pairwise comparison of the average abundances of RCs of dominant species per ecotype of the mangrove stand in (A) Gloria, (B) Bansud, and (C) Bongabong. RCs with the same letters are not statistically significant at $\mathrm{p} \geq 0.05$. Comparison between species (uppercase letters); within species (lowercase letters) based on the p-values given by Wilcoxon and Kruskal Wallis tests. Absence of letters means no particular $\mathrm{RC}$ recorded. 


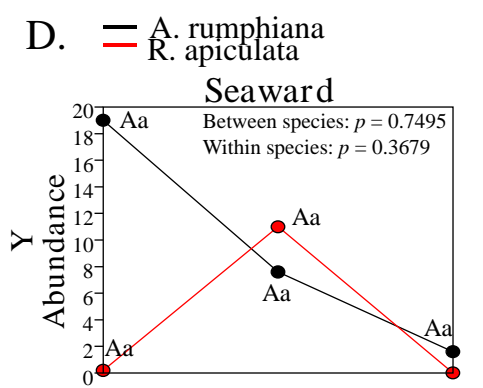

E.
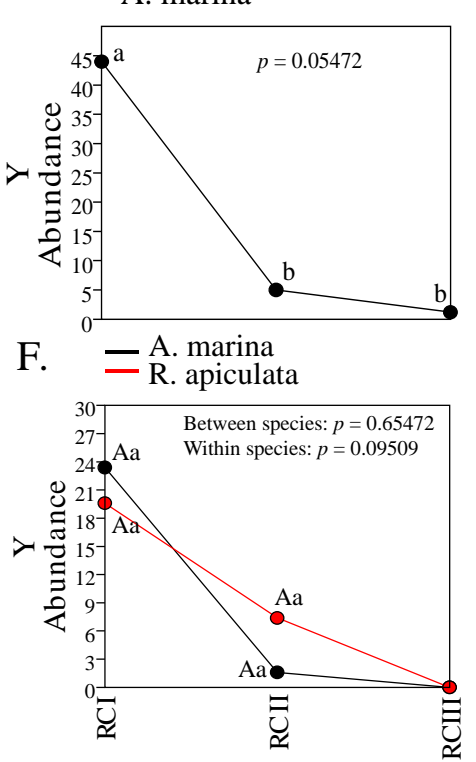

Regeneration Class

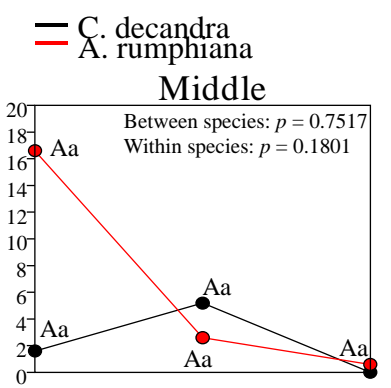

A. marina
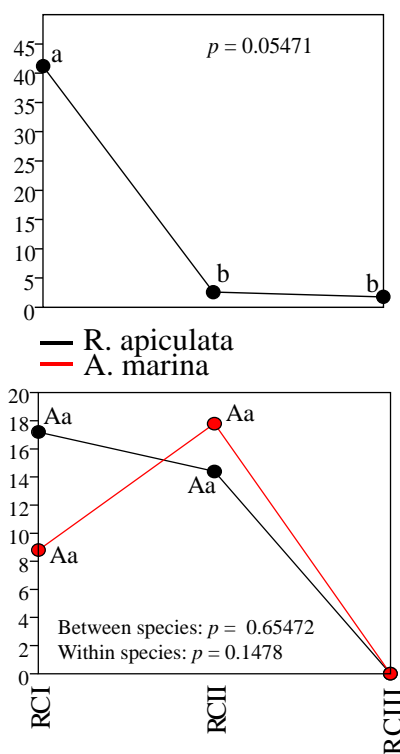

Regeneration Class
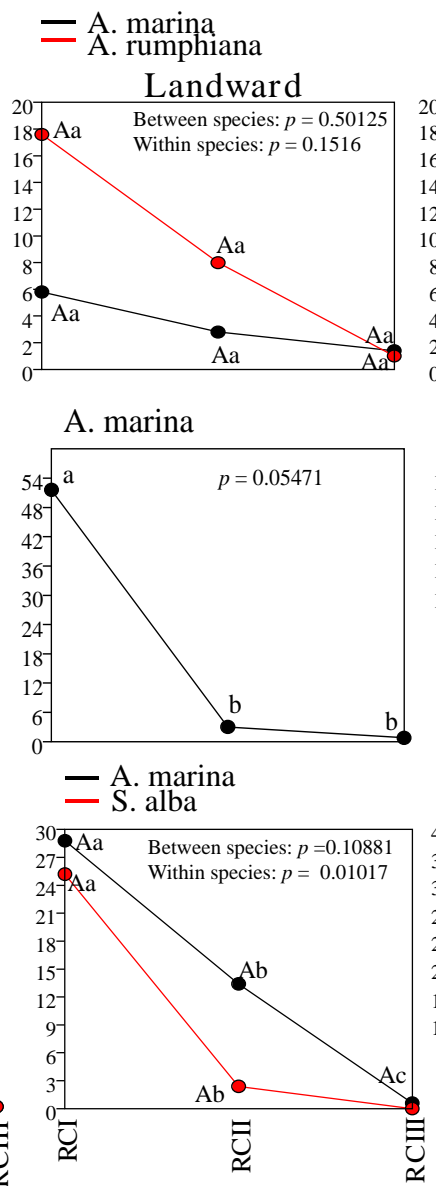

Regeneration Class
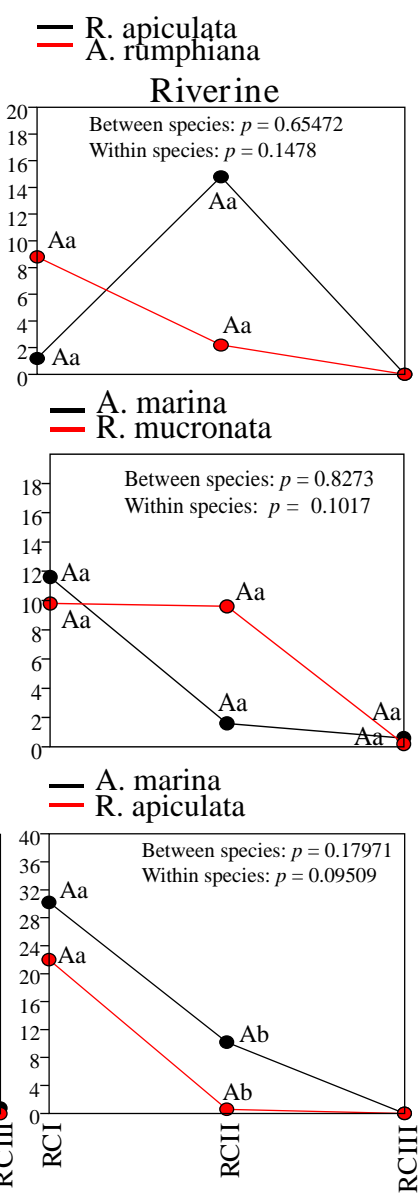

Regeneration Class

Figure 4. Pairwise comparison of the average abundances of RCs of dominant species per ecotype of the mangrove stands in (D) Roxas, (E) Mansalay, and (F) Bulalacao. RCs with the same letters are not statistically significant at $\mathrm{p} \geq 0.05$. Comparison between species (uppercase letters); within species (lowercase letters) based on the p-values given by Wilcoxon and Kruskal Wallis tests. Absence of letters means no particular RC recorded

Table 2. Threats observed in six mangrove ecosystems in the southern coast of Oriental Mindoro, Philippines

\begin{tabular}{|c|c|c|c|c|c|c|c|}
\hline \multirow{2}{*}{$\begin{array}{l}\text { Threats } \\
\mathrm{N}=113 \text { respondents }\end{array}$} & \multicolumn{7}{|c|}{ Respondents' responses per site } \\
\hline & $\begin{array}{l}\text { Gloria } \\
n=20\end{array}$ & $\begin{array}{l}\text { Bansud } \\
\mathrm{n}=20\end{array}$ & $\begin{array}{l}\text { Bongabong } \\
\mathrm{n}=14\end{array}$ & $\begin{array}{l}\text { Roxas } \\
n=20\end{array}$ & $\begin{array}{l}\text { Mansalay } \\
\mathrm{n}=9\end{array}$ & $\begin{array}{l}\text { Bulalacao } \\
n=30\end{array}$ & $\begin{array}{r}\text { Length of time } \\
\text { observed (years) }\end{array}$ \\
\hline Urbanization (Immigration) & $5(25)$ & $17(85)^{*}$ & 0 & $20(100) *$ & 0 & $30(100)^{*}$ & $\geq 30$ \\
\hline Aquaculture & $2(10)$ & 0 & $13(93)^{*}$ & $15(75)^{*}$ & $8(89)^{*}$ & $21(70)^{*}$ & $\geq 30$ \\
\hline Agriculture & $13(65)^{*}$ & 0 & $1(7)$ & $6(30)$ & $9(100)^{*}$ & 0 & $\geq 30$ \\
\hline Water pollution & $6(30)$ & $5(25)$ & $2(14)$ & $20(100) *$ & $4(44)$ & $4(13)$ & $10-15$ \\
\hline $\begin{array}{l}\text { Illegal logging/ cutting of } \\
\text { mangrove trees }\end{array}$ & $4(20)$ & $13(65)^{*}$ & $2(14)$ & $3(15)$ & $7(78)^{*}$ & $17(57)^{*}$ & $\geq 30$ \\
\hline $\begin{array}{l}\text { Used mangroves as raw } \\
\text { materials for tannin extraction, } \\
\text { charcoal making, etc. }\end{array}$ & $5(25)$ & $1(5)$ & $2(14)$ & $3(15)$ & $3(33)$ & $5(17)$ & $\geq 30$ \\
\hline Coastal Erosion & $6(30)$ & $2(10)$ & $4(29)$ & $4(20)$ & $2(22)$ & 0 & $\geq 20$ \\
\hline Flooding & $9(45)$ & $2(10)$ & $3(21)$ & $3(15)$ & 0 & $2(7)$ & $\geq 20$ \\
\hline Sea Level Rise & $12(60)^{*}$ & $5(25)$ & $9(64)^{*}$ & $5(25)$ & $2(22)$ & 0 & $\geq 20$ \\
\hline Storm surges/ strong tidal waves & $4(20)$ & 0 & $2(14)$ & $4(20)$ & $3(33)$ & 0 & $\geq 15$ \\
\hline Siltation & $3(15)$ & 0 & $1(7)$ & $3(15)$ & $2(22)$ & $4(13)$ & $\overline{5}-20$ \\
\hline Increase in temperature & $14(70)^{*}$ & $20(100)^{*}$ & $13(93)^{*}$ & $20(100)^{*}$ & $7(78)^{*}$ & $24(80)^{*}$ & $10-15$ \\
\hline Change in precipitation patterns & $13(65)^{*}$ & $20(100)^{*}$ & $13(93)^{*}$ & $20(100) *$ & $7(78)^{*}$ & $20(67)^{*}$ & $10-15$ \\
\hline
\end{tabular}

Note: N: total number of respondents in all study sites; $n$ : total number of respondents per study site. Value inside parenthesis is the percentage of the respondents based on their responses toward observed threats. Asterisk (*) means frequently observed threats and zero (0) means threats not observed at all. 


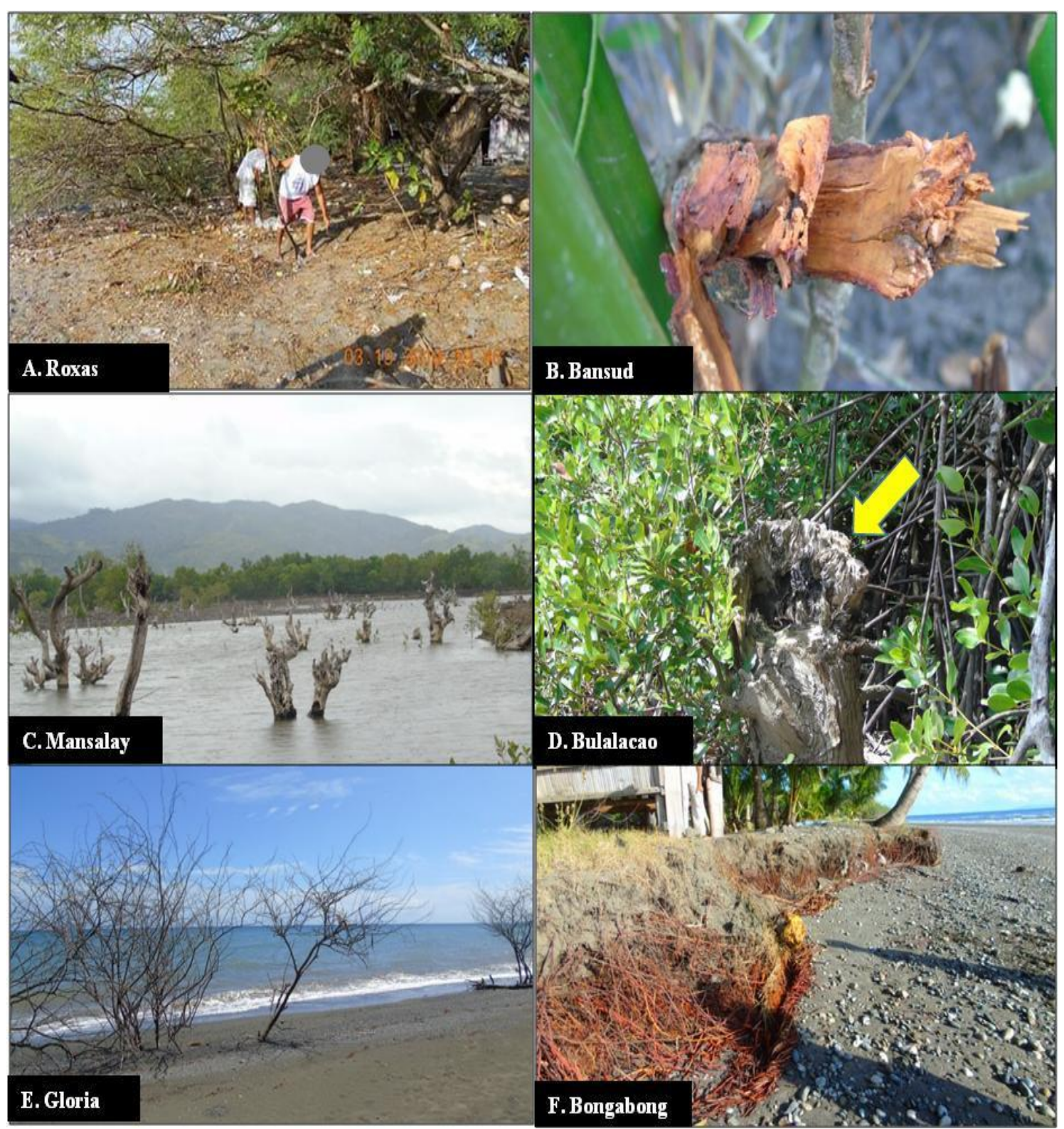

Figure 5. Some threats observed from the mangrove areas in the southern coast of Oriental Mindoro, Philippines. (A) pollution due to household wastes along the shore of Roxas (photo credits to J. Ortega); (B-D) cutting of mangrove trees in Bansud, Mansalay, and Bulalacao; (E) remnants of dead trees along the shore of Gloria and (F) coastal erosion along the shore of Bongabong

Sea level rise has been constantly observed in some municipalities except in Bulalacao where respondents did not perceive that it happened. The remnants of dead trees along the coast of Gloria (Figures 5.E) and erosion of coastal soils in Bongabong (Figures 5.F), evidently indicated the rise of sea level in these areas. Respondents from the study sites also emphasized that climatic factors such as change in precipitation patterns and temperature were frequently observed in all sites. Accordingly, these climatic events vary each year, wherein even during summer months they usually experience heavy rainfall. Other threats such as siltation, typhoon surges, flooding, coastal erosion, and extraction of mangroves for other uses were also observed in other sites but not that frequent.

\section{Discussion}

The identification of dominant mangrove species in each ecotype had shed light on knowing what species are suitable for a particular zone in each respective mangrove stand. However, our study found out that a particular mangrove species under the genera Avicennia and Rhizophora can dominate most of the zones or the entire mangrove stand in all study sites. For example, Rhizophora species dominates in the entire mangrove stand of Gloria. Similar pattern was also apparent in the mangrove stands of Bansud and Bongabong where Avicennia species dominate in all zones. Whereas, both genera dominate in the mangrove stand of Roxas, particularly A. rumphiana and $R$. apiculata species. Species A. marina dominates in all zones 
of the mangrove stand in Mansalay and co-dominated by Rhizophora species in Bulalacao. Results show that the dominant mangrove species in the southern coast of Oriental Mindoro are the genera Avicennia and Rhizophora. It was somehow difficult to distinguish zonation patterns in these mangrove stands.

The dominance of mangrove species over a particular ecotype is driven by the specific conditions of the mangrove environment, where they develop morphoanatomical characteristics that could adapt into it. Such characteristics include superficial rooting systems that serve as their adaptive strategy determining their actual distribution patterns (Srikanth et al. 2015). Feller et al. (2010) and Srikanth et al. (2015) reported different types of rooting systems among mangrove species. Accordingly, species with pneumatophore root systems such as $A$. marina and $S$. alba are usually found thriving in the seaward zone, hence, considered salt-tolerant species. Those species with prop and knee root systems such as Rhizophora and $C$. decandra are usually found in the middle and riverine zones. Species $X$. granatum with buttress root is commonly found abundant inland of the mangrove forest. These rooting characteristics are comparable to the dominant mangroves and their distribution patterns in the study areas. However, we found out that a particular species under genera Avicennia and Rhizophora have the capacity to dominate the entire mangrove stand. Our results agreed with the findings from other studies stating that not all mangrove vegetation shows distinct zonation patterns (Schmiegelow et al. 2014; Eswaran et al. 2017).

With regards to regeneration capacity of the mangrove sites, there is a degree of disparity when it comes to the abundances and size classes of the regenerants. We found out that RCI (seedlings) are the most abundant and sometimes significantly higher among the RCs. Though, there were occurrences that RCs II (saplings) and III (small trees) were found more abundant than the RCI. The abundance of seedlings in the study sites is attributed to the profuse reproduction of the dominant mangrove species during the time of survey. Similarly, amongst all the RCs, RCIII was considered to be the least abundant in all mangrove areas. There were instances that no RCIII had been encountered at all. This study assumes that maybe competition took place among the juveniles especially for space, sunlight, and soil nutrients contributing to the very low density or complete absence of RCIII in some areas. For instance, the density-dependent and independent concept in ecology explain the regulation of population density in a certain forest community as affected by these environmental factors. Other factors such as exposure to flooding due to tidal inundation and high salinity are among the potential factors in the low progression rate or possible death of the juveniles. Many studies reported that even the juveniles of salt-tolerant species $A$. marina and $S$. alba cannot withstand high salinity and are having low growth performances in this condition (Ball et al. 1995; Kodikara et al. 2018; Cheng et al. 2020; Feng et al. 2020).

The abundance of seedlings in all mangrove sites may imply the occurrence of disturbances within the mangrove stand which opened up the area leading to the profuse regeneration of the ecosystem (Alemayehu et al. 2017). Such disturbances are directly associated with human actions particularly cutting of mangrove trees due to fishpond establishment that resulted in the opening of forest canopy of the mangrove forest. Accordingly, in places where a disturbance has occurred and the cover has been opened, more light enters and facilitates the establishment of seedlings of a certain species (Alemayehu et al. 2017). Growth and stem sizes may vary among juvenile plants depending on the amount of light they received (Clark and Clark 1992; Jiang et al. 2019). The seedlings that initially establish in the understory and subsequently experience a gap opening are more likely to progress, reach maturity, and reproduce successfully (López-Hoffman et al. 2007). The variation in the density and abundance of juveniles may also depend on the ecology of species and their adaptability to the prevailing conditions in a particular ecotype. The type of soil and seed structure may contribute to the differences in the regeneration pattern of each mangrove species (Mchenga and Ali 2014). Sediment accretion in different ecotypes can be another factor in the variation of density and abundance, since it can also affect the establishment of mangrove seedlings (Balke et al. 2013). In addition, study showed a low regeneration trend in flood-prone ecotype such as the riverine zone in some mangrove areas (Roxas, Mansalay, Bulalacao). We presume that regeneration in this ecotype is low since it is always exposed to flooding, though it was not the case in all mangrove areas. We are certain that the difference in regeneration densities in ecotypes is governed by the types of disturbances, structure, and the phenology of mangrove species as mentioned earlier.

The specific threats observed in each mangrove area can probably inflict negative impacts on the regeneration capacity of the mangrove ecosystem. The use of harmful chemicals from the agricultural activities in Gloria and Mansalay can impose toxicity effect on the juvenile mangroves when chemicals are discharged to water bodies affecting their growth (Lewis et al. 2011). Tidal action due to sea-level rise can also affect the regeneration capacity, especially in the seaward zone, because it can possibly wash out and suffocate seedlings from being flooded. Sea level rise can impact the mangrove ecosystem if regeneration did not succeed. The impact of this threat will create higher salinity concentration, along with higher $\mathrm{CO}^{2}$, and temperature affecting the future distribution, abundances, and viability of various mangrove species (Kareiva et al. 1993; Yáñez-Espinosa and Flores 2011). But this can be mitigated when regeneration rate is higher which we highly expect for the study sites. Studies suggest that mangroves can adapt to sea-level rise if it occurs slowly. They may adapt growing inland on more elevated areas, probably increasing their distribution (YáñezEspinosa and Flores 2011). Moreover, the selective cutting of mangrove trees in Bansud, Roxas, and Bulalacao as well as the increase in population near these mangrove areas can impact mangroves' recovery since these areas are open access to community. It has been reported that the source of mangrove degradation is directly accounted to the local 
residents (Fent et al. 2019). Possible impact would be crushing and trampling of young plants due to constant access. The existing fishpond operations within the mangrove stands in Bongabong, Roxas, Mansalay, and Bulalacao are considered a major threat. This can possibly slow down the recovery of the mangrove stands if not mitigated or at least minimized.

Climatic events such as prolonged precipitation and droughts could also affect the regeneration and establishment of mangrove seedlings in the study areas. High temperature can lead to droughts in the soil and extensive precipitation can cause flooding affecting the establishment of seedlings across flood-prone zones (seaward and riverine). However, temperature change in the tropics may not be as great compared with the temperate regions (Solomon et al. 2007; Beaumont et al. 2011). In our study, we cannot clinch to the idea that regeneration can be directly affected by drought, because based on the results of our interview, rainfall has been observed even during summer months. So the impact on regeneration could be linked more with the hydrologic events. Perhaps, from the ecological point of view, the increase in temperature can actually push mangroves to invade the inland areas (Doyle 2003; Yáñez-Espinosa and Flores 2011). Moreover, changes in precipitation patterns, soil water content, as well as salinity, can lead to variations in mangrove species growth and composition (Carugati et al. 2018). Aside from the natural and anthropogenic stressors mentioned, physical disturbance like enigmatic ecological degradation driven by freshwater system processes should also be considered. In Sri Lanka, it was reported that the inland freshwater has cryptic effects on the seaward zone through intrusion of excess freshwater (Dahdouh-Guebas et al. 2005). The resulting effect of this cryptic process was the alterations in the composition of mangrove ecosystems, and the dominance of some fresh water-loving mangrove species in the coastal zone (Dahdouh-Guebas et al. 2005). We believe that this scenario also exists in the study sites, hence, we observed low-salt tolerant species (A. rumphiana) dominating in the seaward zone of Roxas. However, mangroves are well adapted to natural phenomena and generally recover quickly from both minor and major episodic disturbances through natural regeneration, even without the need for rehabilitation (Schmitt and Duke 2016; Das et al. 2019). The major advantage of natural regeneration is that the ensuing forest is anticipated to be more alike of its original species composition. In fact, natural regeneration is relatively easy, where seedling establishes well, and the labor demands and soil disturbances are minimal (Alura and Alura 2016).

To conclude, the quantification of the possible mangrove loss as affected by the observed anthropogenic and climatic threats cannot be measured at the moment. Perhaps, this could be a good recommendation for future studies to determine their impacts on changes in species composition (if it happens) and recovery potential of these mangrove areas. The results of the present study provide evidence on the importance of regeneration, and somehow confirming the positive contribution of rehabilitation programs implemented in these mangrove areas. The study cannot yet quantify the regeneration success since most of the juveniles are still under the RCI (seedling) stage. But the presence of these seedlings alone indicates that all mangrove sites have the capacity to regenerate even without human assistance. Given that all of these seedlings will grow successfully, then there would be great hopes for these mangrove ecosystems to recover naturally in the years to come. However, accompanied by regeneration success is closed and constant monitoring of these mangrove areas. Protection of these young plants is important as they dictate the future of these mangrove ecosystems. With these findings, the following management strategies are hereby recommended: (i) promote Assisted Natural Regeneration (ANR) in all mangrove areas, hence, the best way in restoring the ecosystem; (ii) reclamation of the abandoned fishponds and (iii) application of aquasilviculture system instead of destructive fishpond practices.

\section{ACKNOWLEDGEMENTS}

The work described in this paper was supported and funded by the Commission on Higher Education K-12 Transition Program (CHED K-12), Philippines and Asia Pacific Network (APN) through the APNIS Project (Plausible alternative futures of island mangroves in the Asia-Pacific: Scenario-based analysis and quantification of mangrove ecosystem services in coastal hazard mitigation and climate change adaptation (CRRP2018-03MYHashimoto). The authors would also like to thank the provincial and municipal agriculture offices of Oriental Mindoro for their assistance in the conduct of this study. The authors declare no conflict of interests exists in this study.

\section{REFERENCES}

Alemayehu F, Chemuku W. 2017. Structure and natural regeneration of mangroves in areas exposed to different agents of degradation in Kenya. J Glob Biosci 6: 4695-4707.

Alura D, Alura, RP. 2016. Regeneration of mangrove forest devastated by typhoon Haiyan in eastern Samar, Philippines. Intl J Curr Res 8: 32373-32377.

Balke T, Webb EL, van den Elzen E, et al. 2013. Seedling establishment in a dynamic sedimentary environment: A conceptual framework using mangroves. J Appl Ecol 50: 740-747.

Ball M, Pidsley S. 1995. Growth responses to salinity in relation to distribution of two mangrove species, Sonneratia alba and $S$. lanceolata, in northern Australia. Funct Ecol 9 (1): 77-85.

Beaumont LJ, Pitman A, Perkinsc S, et al. 2011. Impacts of climate change on the world's most exceptional ecoregions. Proc Natl Acad Sci 108 (6): 2306-2311.

Begam MM, Chowdhury R, Sutradhar T, et al. 2020. Forecasting mangrove ecosystem degradation utilizing quantifiable ecophysiological resilience-A study from Indian Sundarbans. Sci Rep 10: 6683.

Carugati L, Gatto B, Rastelli E, et al. 2018. Impact of mangrove forests degradation on biodiversity and ecosystem functioning. Sci Rep 8: 13298.

Cayabyab N. 2014. Assessing the vulnerability of the fisheries and coastal integrity of the 13 coastal municipalities and a city in Oriental 
Mindoro: A mangrove assessment report. State of the Mangrove Summit: Northwestern Luzon Proceedings 2015. [Philippines]

Cheng H, Inyang A, Li C, Fei J, Zhou Y, Wang Y. 2020. Salt tolerance and exclusion in the mangrove plant Avicennia marina in relation to root apoplastic barriers. Ecotoxicology 29: 676-683.

Chowdhury R, Sutradhar T, Begam MM, et al. 2019. Effects of nutrient limitation, salinity increase, and associated stressors on mangrove forest cover, structure, and zonation across Indian Sundarbans. Hydrobiologia 842: 191-217.

Clark DA, Clark DB. 1992. Life history diversity of canopy and emergent trees in a neotropical rain forest. Ecol Monogr 62: 315-344.

Curnick DJ, Pettorelli N, Amir AA, et al. 2019. The value of small mangrove patches. Science 363: 239

Dahdouh-Guebas F, Hettiarachchi S, Lo Seen D et al. 2005 Transitions in ancient inland freshwater resource management in Sri Lanka affect biota and human populations in and around coastal lagoons. Curr Biol 15: 579-586.

Das L, Patel R, Salvi H, Kamboj RD. 2019. Assessment of natural regeneration of mangrove with reference to edaphic factors and water in Southern Gulf of Kachchh, Gujarat, India. Heliyon 5 (8): e02250. DOI: 10.1016/j.heliyon.2019.e02250.

Doyle TW. 2003. Predicting future mangrove forest migration in the everglades under rising sea level: USGS Fact Sheet FS-030-03; U.S Department of the Interior, U.S. Geological Survey, Washington, DC.

Duncan C, Primavera J, Pettorelli N, et al. 2016. Rehabilitating mangrove ecosystem services: A case study on the relative benefits of abandoned pond reversion from Panay Island, Philippines. Mar Pollut Bull 109 (2): 772-82.

Eswaran Y, Dharanirajan K, Subramanian J, et al. 2017. Distribution and zonation pattern of mangrove forest in Shoal Bay Creek, Andaman Islands, India. Indian J Mar Sci 46: 597-604.

Feller C, Lovelock CE, Berger U, McKee KL, Joye SB, Ball MC. 2010 Biocomplexity in Mangrove Ecosystems. Ann Rev Mar Sci 2: 395417.

Feng X, Xu S, Li J, Yang Y, Chen Q, Lyu H, Zhong C, He Z, Shi S. 2020 Molecular adaptation to salinity fluctuation in tropical intertida environments of a mangrove tree Sonneratia alba. BMC Plant Biol 20: 178 .

Fent A, Bardou R, Carney J, Cavanaugh K. 2019. Transborder political ecology of mangroves in Senegal and The Gambia. Global Environ Change 54: 214-226.

Garcia K, Gevaña D, Malabrigo P. 2013. Philippines' Mangrove Ecosystem: Status, Threats, and Conservation. Springer, Science+Business Media, New York.

Ghosh S, Bakshi M, Bhattacharyya S, Nath B, Chaudhuri P. 2015. A review of threats and vulnerabilities to mangrove habitats: with special emphasis on east coast of India. J Earth Sci Clim Change 6: 270.

Jiang Z, Guan W, Xiong Y, et al. 2019. Interactive effects of intertidal elevation and light level on early growth of five mangrove species under Sonneratia apetala Buch. Hamplantation canopy: Turning monocultures to mixed forests. Forests 10 (2): 83.
Kareiva PM, Kingsolver JG, Huey RB. 1993. Biotic Interactions and Global Change, Sinauer Associates Inc., Sunderland, USA

Kathiresan K, Saravanakumar K, Anburaj R, Gomathi V. 2016. A simple method for assessing mangrove forest based on young plants and sesarmid crab holes. Reg Stud Mar Sci 7: 204-210.

Kathiresan K. 2018. Mangrove forests of India. Curr Sci 114: 976-981.

Kodikara AS, Jayatissa LP, Huxham M, Dahdouh-Guebas F, Koedam N. 2018. The effects of salinity on growth and survival of mangrove seedlings change with age. Acta Bot Bras 32 (1): 37-46.

Krauss KW, Lovelock CE, McKee KL, et al. 2008. Environmental drivers in mangrove establishment and early development: A review. Aquat Bot 89 (2): 105-127.

Lewis M, Pryor R, Wilking L. 2011. Fate and effects of anthropogenic chemicals in mangrove ecosystems: A review. Environ Pollut 159 (10): 2328-46.

Lewis RR, Hodgson AB, Mauseth GS. 2005. Project facilitates the natural reseeding of mangrove forests. Ecol Restor 23: 276-277.

López-Hoffman L, Ackerly DD, Anten NP, Denoyer JL, Martinez-Ramos M. 2007. Gap-dependence in mangrove life-history strategies: A consideration of the entire life cycle and patch dynamics. J Ecol 95: 1222-1233.

Mchenga SS, Ali A. 2014. Natural regeneration of mangroves in a degraded and non-degraded tropical forest of Zanzibar Island. J Glob Biosci 3 (1): 334-344.

Primavera JH, Rollon RN, Samson MS. 2011. The pressing challenges of mangrove rehabilitation: Pond reversion and coastal protection. In: Reference Module in Earth Systems and Environmental Sciences. Treatise on Estuarine and Coastal Science. Elsevier, Amsterdam.

Primavera JH, Sabada RS, Lebata MJHL, Altamirano JP. 2004. Handbook of Mangroves in the Philippines-Panay. SEAFDEC Aquaculture Department, Iloilo, Philippines.

Schmiegelow J, Marcos M, Gianesella S, Maria F. 2014. Absence of zonation in a mangrove forest in southeastern Brazil. Braz J Oceanogr 62 (2): 117-131.

Schmitt K, Duke NC. 2016. Mangrove management, assessment, and monitoring L. Pancel, M. Köhl (Eds.), Tropical Forestry Handbook, Springer, Berlin, Heidelberg.

Solomon S, Qin D, Manning M, et al. 2007. Contribution of Working Group I to the Fourth Assessment Report of the Intergovernmental Panel on Climate Change. In: Solomon S, Qin D, Manning M, Chen Z, Marquis M, Averyt K.B, Tignor M, Miller HL (eds.). Climate Change 2007, The Physical Science Basis. Cambridge University Press, Cambridge, UK.

Srikanth S, Lum S, Chen Z. 2015. Mangrove root: adaptations and ecological importance. Trees 30: 451-465.

Yáñez-Espinosa L, Flores J. 2011. A Review of Sea-level rise Effect on Mangrove Forest Species: Anatomical and Morphological Modifications. Global Warming Impacts-Case Studies on the Economy, Human Health, and on Urban and Natural Environments. Stefano Casalegno, IntechOpen, UK. 